\title{
Why Farmers Adopt Agro-Industrial By-Products in Animal Feed? Lesson Learned in Algerian Case
}

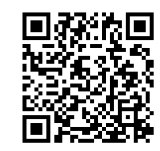

\author{
Fateh MAMINE ${ }^{1 *}$, Noure El Imène BOUMALI ${ }^{2}$, Etienne MONTAIGNE ${ }^{3}$ and Fodil ARBOUCHE \\ ${ }^{1}$ Départment ACT, Bâtiment 22, 02 place Pierre Viala, 34060 Montpellier, France. \\ ${ }^{2}$ UMR Moisa-SupAgro, 2 place Pierre Viala, 34060 Montpellier, France \\ ${ }^{3}$ UMR Moisa, 2 place Pierre Viala, 34060 Montpellier, France \\ ${ }^{4}$ Department of Agronomy, University of Gharaia, 47000, Algeria
}

Submission: August 06, 2020; Published: September 17, 2020

"Corresponding author: Fateh MAMINE, UMR Selmet-INRAE, Département ACT, Bâtiment 22, 02 place Pierre Viala, 34060 Montpellier, France

\begin{abstract}
The Algerian animal sectors suffer from a major handicap which is the insufficiency of fodder resources. The current structure of the animal feed industry is essentially based on the imported raw material (corn and soybean meal). It is in this logic that this study teat the problem of adoption of agro-industrial by-products as innovative inputs in animal feed. Our results based on a logistic model analysis with re-sampling applied to the survey data of farmers in the Souk Ahras region of northeastern Algeria show that the adoption of this innovation is determined by several factors related to the socio-professional profile of the farmer and the structure of the breeding. The seasonality that characterizes the availability of these by-products does not constitute an obstacle to their use by farmers. The diffusion of these new techniques will require public institutions' support through better dissemination of information and specialized training in this area.
\end{abstract}

Keywords: Algeria; By-products; Innovation adoption; Animal feeding; Farmer's choice

\section{Introduction}

In the manner of all the semi-arid countries, the pastures provide the primary fodder source. Their surface in Algeria represents nearly 40 million hectares. The cultivated fodder resources consist of cereal stubble, vegetation grazed fallow representing $97.7 \%$ of the total forage area, some cultivated fodder $(1.95 \%)$ and natural fodder $(0.51 \%)$. These areas are characterized by low forage productivity [1]. The insufficiency in animal feeding, regression land, limited use of resources on the part of farmers, remains a topical issue given that availability is closely linked to market prices regulated by supply and request. Faced with this situation, Algeria chooses to import to fill the shortfall of feeds in the local market. According to the National Office of Animal Feed Food (ONAB) 3 million tons of maize are required to meet annual national needs. The Algerian government has decided to support and accompany the development of maize and barley. Thus, it is committed to filling the shortfall by encouraging the development of local production of barley and maize by buying at a higher price than the import. Local production of maize is well supported with 4500 DA/q (32€/q), against $17.9 € / q$ for the imported one. Despite efforts, Algeria could not meet the market needs in livestock feed because it requires an estimated area of 200000 and 300000 hectares of maize (against leas than 1000 ha cultivated actually in Algeria), knowing that this crop needs lots of water in a semiarid country. Imported material feed matter generates significant costs to the Algerian state. In 2014, the purchase of maize cost 977.13 million \$ and barley 196.6 million $\$$. During the last twenty years, and to meet the growing demand for animal products, maize imports have increased more than 10,000 times and soybean meal by nearly 7,000 times (ONS 2017). However, agroindustrial by-products, "waste in their current state", are available in appreciable quantity, allowing their integration in the animal feed sector although their use requires nitrogen treatments or complementation. These can contribute to the improvement of animal feed in the region where they come from. These are, in particular, the milling bran, tomato and citrus pulp, molasses, olive-pomace, grape marc, brewers dried grains, and apricot pits. Some are energy supplements such as molasses and pulp, others are protein supplements such as almond of apricot and brewers dried grains [2]. The work of [3-5] has demonstrated the technical utility of using these by-products in the feed industry through 
partial substitution of raw materials (soybean meal and maize).

Agro-industrial factories generate various by-products, farmers may be asked to use it in their food rations. However, accurate information and knowledge on these by-products seem necessary for their adoption in farms. This article aims to analyze the factors influencing the adoption by farmers of these by-products in feeding their flocks. This paper can serve as a guide to a public policy whose objective is to enhance feed resources management and animal production by developing an agroecological practice (valorize agro-industrial waste). It includes three sections. After this introduction presenting the context of the study, section 2 presents the methodology of the study starting from the sample to the establishment of the questionnaire, and finally, the choice of variables and statistical analyses used. Section 3 presents the results and discussion and includes two subsections: a food management characterization of the surveyed farms and an analysis of the determinants of adoption of innovative input in the diet of livestock. A conclusion at the end of the paper to return to the main results of this study and the prospects for their implementation by public power in livestock development.

\section{Material and Methods}

\section{Study setting and sample}

The objective is to analyze the factors that determine the use of by-products and their place in the food structure of livestock farms. Thus, we have investigated farmers in the region of Souk Ahras, the major cradle of animal production in Algeria. The choice of the survey area is justified by the geographical location of this region where farmers benefit from the proximity not only of livestock feed industries but also agro-industrial factories emitting by-products subject of our study. This region is also known for the diversity of farming systems adapted to its representative bioclimatic three floors of the country namely a rainy mountainous area (600 mm/year) temperate lowland area (400 mm/year) and finally an area of high semiarid trays (less than $350 \mathrm{~mm} / \mathrm{year}$ ). The survey was conducted in 2017 with a random sample of 57 farmers who agreed to be interviewed. The survey was conducted face-to-face in front of the feed outlets to target concentrated feed users, breeders subject to our study. After verification of survey results, only 40 questionnaires were validated and used in the analysis.

\section{Questionnaire and Variable selection}

The study questionnaire consisted of four sections. The first relates to the individual characteristics of farmers interviewed (age, experience, level of education, agricultural training at the installation, participation in information days and agricultural training organized by the Chamber of Agriculture). The second section seeks to identify the farm characteristics and practices (UAA, labor, manpower and high species). The third part seeks to characterize the food management of livestock (feed used and their quantities, supplying). Finally, the last part is devoted to assessing the attitudes of farmers towards agro-industrial byproducts. Here we first look to find out if farmers know these by-products before asking if they use them in the feed of their livestock and their perceived level of availability in the market.

To analyze the determinants to use innovative inputs (agroindustrial by-products) in animal feed, the collected data were transcribed and then treated by the SPSS statistical analysis software. Here we identified two dependent variables (Byprod know and Byprod_use) (Table 1), but at the survey verification phase, we found that the surveyed farmers know at least two byproducts from the list we presented to them (the milling bran, tomato and citrus pulp, molasses, olive-pomace, grape marc, brewers dried grains and apricot pits). That's why we did not do statistical analyzes in connection with the first dependent variable (Byprod_know). To analyze in connection with the by-products use, we first characterized the feed management of surveyed farms and defined a set of variables describing the individual characteristics of the farmers, farm characteristics and finally byproducts market characteristics (Table 1). These dimensions are considered by the literature specialized in the issue as the main factors influencing the decision to adopt the innovation in the agricultural environment [6-8].

Table 1: Variables presentation.

\begin{tabular}{|c|c|c|c|}
\hline Variable & Definition & Mean & ES \\
\hline Byprod_know & $0=$ no; 1 = yes & 0.9 & 0.04 \\
\hline Byprod_use & $0=$ no; 1 = yes & 48.7 & 1.94 \\
\hline Age & Farmer's age & 20.32 & 2.32 \\
\hline Experience & Years of experience in breeding & 1.35 \\
\hline Education & $\begin{array}{c}0=\text { unschooled; } 1=\text { primary; } 2=\text { fundamen- } \\
\text { tal; } 3=\text { secondary; } \text { = high school than }\end{array}$ & 0.07 & 0.05 \\
\hline Training_instal & $0=$ no; 1 = yes & 0.42 & 0.13 \\
\hline Information_day & $0=$ no; 1 = yes & 2.15 & 0.28 \\
\hline Manpower & Number of labors in the farm & 14.27 & 2.09 \\
\hline UAA & Agricultural area (ha) & \\
\hline
\end{tabular}


Annals of Social Sciences \& Management studies

\begin{tabular}{|c|c|c|c|}
\hline Cattle & adult cattle in the farm (head) & 10.55 & 1.54 \\
\hline Sheep & adult sheep in the farm (head) & 13.12 & 2.54 \\
\hline Poultry & $\begin{array}{l}\text { Poultry produces annually in the farm } \\
\text { (head) }\end{array}$ & 1475 & 1033 \\
\hline Supplying_difficulty & 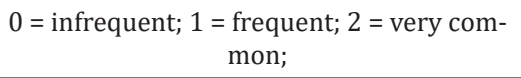 & 0.35 & 0.07 \\
\hline Supplier & $\begin{array}{c}0=\text { animal feed factory; } 1=\text { cooperative; } 2 \\
=\text { private; } 3=\text { Agro-industrial factory; } 4= \\
\text { other }\end{array}$ & 1.85 & 0.08 \\
\hline Byprod_availability & $0=$ no; $1=$ yes & 0.475 & 0.07 \\
\hline
\end{tabular}

\section{Statistical analysis}

A binary logistic model (Byprod_use) with a bootstrap resampling (100 replicates) was employed to process the data. This method resampling is highly relevant to analyze the determinants of the innovation adoption and address the lack of answers or a low sample size [7]. It has the advantage of weighted estimates reflect the true population parameters [8-11]. To analyze the results of the model, three thresholds of statistical significance ( $p$ $\leq 0.1 ; \mathrm{p} \leq 0.05 \mathrm{p} \leq 0.01$ ) were fixed.

\section{Results and Discussion}

The livestock farms surveyed use both dry forages (hay) but also concentrated feed (barley, compound feed). The amounts and diversity of feed inputs depend on herd size and production purposes (milk, red meat, white meat). The feed inputs of cattle farms surveyed are dominated by concentrated feed which represents $60 \%$ of the total tonnage consumed, equivalent to $360 \mathrm{q} /$ year (Table 2). These results confirm the importance of concentered feed as a main input in the surveyed farms and show the relevance of our sample to address the issue of the place of by-products in the management of feed inputs and the possibility of conventional inputs substitution. The remaining $40 \%$ of feed inputs include barley that is another concentrated. By feed inputs insufficiency, the cereal straw is an agricultural by-product that systematically used in ruminant feed, so we did not consider it in our study as an innovative input into animal feed. Cereal straw represents $13.5 \%$ of consumed inputs (the equivalent of $80 \mathrm{q} /$ year) which is a non-negligible share of feed inputs especially considering its cost of $290 \mathrm{DA} / \mathrm{bale}$ of straw of $18 \mathrm{~kg}$ for average annual spending of 130,540 DA/year. However, the first item of expenditure in feed inputs remains the concentrated feed with $1,284,287 \mathrm{DA} /$ year before the hay that costs $290,320 \mathrm{DA} /$ year.

Table 2: Descriptive statistics of the components of feed management.

\begin{tabular}{|c|c|c|c|c|}
\hline Variables & Min & Max & Mean & SD \\
\hline Consumed hay (haystack of $25 \mathrm{~kg} /$ year) & 0 & 2000 & 592.5 & \pm 490.62 \\
\hline Price of consumed hay (DA/haystack) & 400 & 500 & 490 & \pm 31.62 \\
\hline Consumed straw (bale of straw of $8 \mathrm{~kg} /$ year) & 0 & 2000 & 448.75 & \pm 460.83 \\
\hline Price of straw consumed (DA/bale) & 200 & 300 & 290.9 & \pm 30.15 \\
\hline Consumed barley (q/year) & 0 & 50 & 8.12 & \pm 13.52 \\
\hline Barley price (DA/q) & 3000 & 3500 & 3444.44 & \pm 166.66 \\
\hline Consumed concentrated feed (q/year) & 0 & 1920 & 360.6 & \pm 411.20 \\
\hline Price of consumed concentrated feed (DA/q) & 2500 & 4850 & 3561.53 & \pm 596.64 \\
\hline Distance feed supplier-farm (km) & 1 & 700 & 26.25 & \pm 109.47 \\
\hline
\end{tabular}

Hay and straw are from the production in the farm and/ or purchased from other farms during the harvest season. Concentrated feeds are exclusively purchased from animal feed dealers, cooperatives or directly from animal feed manufacturing units. Indeed, the substitution of a part of concentrated feed by innovative input would be an important opportunity to reduce the animal feed cost and consequently improve the farmer's income. The estimated logistic model shows that 10/13 explanatory variables are significant (Table 3). All individual farmer's characteristics are determinant to by-products adoption as inputs in innovative animal feed. As against certain characteristics of the farm are not significant since it is the herd composition and its size that influence the choice of use of by-products in animal husbandry. Moreover, the type of supplier and the availability of by-products do not seem decisive in the adoption of these new animal feeding inputs. 
Annals of Social Sciences \& Management studies

Table 3: Results of logistic regression (Byprod_use: 0 = no; 1 = yes).

\begin{tabular}{|c|c|c|c|c|}
\hline & Coef. & bootstrap SE & $\mathbf{z}$ & $\mathbf{p}$ \\
\hline Age & -11.61 & 2.91 & -3.99 & $<0.001$ \\
\hline Experience & 2.93 & 1.57 & 1.87 & 0.06 \\
\hline Education & -98.07 & 23.65 & -4.15 & $<0.001$ \\
\hline Traingin_instal & 413.3 & 144.04 & 2.87 & 0.004 \\
\hline Information_day & -109.81 & 35.79 & -3.07 & 0.002 \\
\hline Manpower & 83.87 & 30.41 & 2.76 & 0.006 \\
\hline UAA & 0.98 & 2.19 & 0.45 & 0.652 \\
\hline Cattle & 8.02 & 3.06 & 2.62 & 0.009 \\
\hline Sheep & -1.62 & 0.53 & -3.05 & 0.002 \\
\hline Poultry & -31 & 0.31 & -0.1 & 0.92 \\
\hline Supplying_difficulty & 104.63 & 30.05 & 3.48 & $<0.001$ \\
\hline Supplier & -40.2 & 8430.4 & -0.01 & 0.996 \\
\hline Byprod_availability & -40.37 & 25.83 & -1.56 & 0.118 \\
\hline Constant & 615.39 & 16848.8 & 0.04 & 0.971 \\
\hline
\end{tabular}

The individual characteristics of the farmers are all determinant to by-product adoption as inputs in livestock feed. The age of the farmer seems to influence a very significant decision to use agro-industrial by-products in animal husbandry. Several authors have reported similar results where young farmers are more prone to accept new techniques in agriculture [12-15]. Unlike most older farmers attached to their old practices, young farmers are often more enthusiastic to adopt new techniques in our case the use of new inputs in livestock feed. However, this result is to clarify the experience factor plays a decisive role in the adoption of by-products in animal feed. Results in this direction have been reported by several authors [16-21]. The farmer needs some experience to take this to a new feeding technique. It is usually the case of farmers who have low educational levels which not allowing them to have the needed skills to integrate new technologies in their breeding workshop. As against the farmers with a higher educational level are more skeptical about the by-product use efficiency as an animal feed input. Although several authors have made a positive correlation between the educational level and new techniques acceptance in agriculture [22-24], it seems the opposite in our case. A high educational level creates a perception of more complex and higher risk and makes farmers less receptive to the adoption of innovation [25]. The risk relating to by-products use in animal feed (nutritional values and unknown dosage, the presence of anti-nutritional factors, lack of skills of processing and storage ...) remains a blocking factor for by-product use by farmers even if they participate to information days organized by the Chamber of Agriculture. This is because, according to our investigations, that no information was provided by this agency on the by-product integration possibilities as a new feed source for livestock. The lack of communication on byproduct utility as potential feed input strengthens farmer's risk perception on it. Therefore, it is essential to relativize the impact of the professional network on the decision to adopt the innovation to the extent that it does not disseminate targeted information in its favor.

Our results, however, show that specialized training at the setting-up phase helps to motivate farmers to adopt this new feed technique. This is what was also reported by Yiridoe et al. [26]. In this training, the farmers get the information and skills necessary to use by-products in their breeding workshops. The constant need to provide more effective training to farmers to enable them to understand the characteristics of new technologies is evident in our case. It is always possible to increase the motivation of farmers to adopt innovations by providing them new knowledge through specialized training $[27,28]$.

The results of the estimated model also show that farm characteristics influence the use of by-products. The availability of labor in the farm increases the probability of by-product adoption as inputs in animal feed. It can be explained by the need for additional work related to the by-products supply and process for their use (conservation, storage, dosage). As has been demonstrated by several authors [29-33], unavailability of labor limits new technologies adoption and encourage farmers to practice conventional production.

The farm size expressed by the UAA does not represent in our case a determining factor for the adoption of this new feeding technique. Several studies have had similar results where economies of scale advantage provided by a large farm is not an incentive for the adoption of an innovation [23, 34-35]. The herd composition and size are key factors in the use of by-products in animal husbandry. Our results show that it is the farms with a greater number of cattle that integrate more by-products in animal feed management. Sheep number has the opposite effect and does not encourage farmers to use the by-products. The heavy 


\section{Annals of Social Sciences \& Management studies}

use of compound and concentrated feed in cattle farming is the cause of this finding. Indeed, farmers rely on the by-products use to partially replace conventional feeds of their livestock. Small ruminants are less dependent on the provision of concentrated feed especially since these are small herds managed in a semiextensive way with low inputs. Poultry is almost soilless breeding as it only receives industrial feeds made mainly from soybean and maize [36]. The economic context partly explains by-products adoption in animal feed. Indeed, supply difficulties on the livestock feed market (insufficient quantity, poor quality, and high prices) encourages farmers to look for cheaper alternatives even if they are seasonal [37]. This is also why the by-product's availability and the animal feed supplier type does not influence the farmer's decision to use the by-products. The seasonality that characterizes the production of agro-industrial by-products does not seem to be a barrier to their use in livestock farming, because their use is complementary to that of the concentrated feed and the basic ration. Therefore, different authors advocate thresholds of use to improve the nutritional efficiency of these by-products and to reduce their health risks on livestock [38-44].

\section{Conclusion}

Algerian animal sectors suffer from a major handicap is the lack of forage resources. The current structure of the feed industry is built mainly on imported raw material (soybean meal and maize) where the share of domestic production is marginal. In this situation of the livestock sector fragility, the search for alternatives to import to reduce public spending and better use of local resources is more than ever a necessity. It is in this sense that our work fits. It is built around the issue of the valuation of agro-industrial by-products as an innovative input in livestock feed. We performed our study on the incentives for the adoption of a wide range of by-products available in the country that has undergone extensive nutrition research in animal feed (the milling bran, tomato and citrus pulp, molasses, olive-pomace, grape marc, brewers dried grains and apricot pits). Our study shows that the adoption of this innovation is determined by several factors, first of all, related to the farmers' socio-professional profile where specialized training in the installation can be an important lever for the State to strengthen the diffusion of this new feeding technique. Unlike the herd composition and size that may influence the farmer's decision, the farm size has not influenced the adoption of these innovative feed inputs in farming. Cattle breeding, given its high dependence on concentrated feed, seems more conducive to the use of agro-industrial by-products, hence the need to focus more research on that niche. Intensive farming is often synonymous with a higher need for feed resources opens the way for the by-products use to bridge the feed gap and to reduce costs that result. The seasonality that affects the agro-industrial by-products availability does not seem to hinder their adoption by farmers. However, the diffusion of these new technologies will require more public support through improved information dissemination and specialized training in this filed.

\section{References}

1. Senoussi A, Behir T (2010) Étude des disponibilités des aliments de bétail dans les régions sahariennes. Cas de la région du Souf. Revue du chercheur 8(8): 65-74.

2. Arbouche R, Arbouche F, Arbouche HS, Arbouche Y (2007) Valeur nutritive d'un oléagineux dans l'alimentation des ruminants: cas de l'amande d'abricot et de son tourteau. Livestock Research for Rural Development 19: 189

3. Arbouche F, Arbouche R, Arbouche HS, Arbouche Y (2008) Valeur nutritive d'un oléagineux local et ses dérivés pour l'alimentation du bétail: cas de l'arachide « petite Kaloise» Algérie. Livestock Research for Rural Development 20: 214

4. Arbouche R, Arbouche F, Arbouche HS, Arbouche Y (2012) Effets de la nature du complément azoté (tourteau d'amande d'abricot vs tourteau de soja) sur les performances d'engraissement et la qualité des carcasses des agneaux Ouled Djellal (Algérie). Revue Médecine Vétérinaire 165: 338-343.

5. Arbouche R, Arbouche Y, Mennani A, HS Arbouche, Arbouche F (2017) Valorisation des issues de meunerie de quelques variétés de blé tendre endémiques à Algérie pour l'alimentation des ruminants. Journal of Advanced Research in Science and Technology 4: 529-545.

6. Feder G, Umali DL (1993) The adoption of agricultural innovations: a review. Technological forecasting and social change 43(3-4): 215-239.

7. Bobrowski P, Bretschneider S (1994) Internal and external interorganizational relationships and their impact on the adoption of new technology: an exploratory study. Technological Forecasting and Social Change 46(3): 197-211.

8. Knowler D, Bradshaw B (2007) Farmers' adoption of conservation agriculture: A review and synthesis of recent research. Food policy 32(1): 25-48.

9. Lambert DM, English BC, Harper DC, Larkin SL, Larson JA, et al. (2014) Adoption and frequency of precision soil testing in cotton production. Journal of Agricultural and Resource Economics 39: 106-123.

10. Pan W, Bai H (2015) Propensity score interval matching: using bootstrap confidence intervals for accommodating estimation errors of propensity scores. BMC medical research methodology 15: 53.

11. Bello AO, Oguntolu FA, Adetutu OM, Ojedokun JP (2015) Application of Bootstrap Re-sampling Method to a Categorical Data of HIV/AIDS Spread across different Social-Economic Classes. Scientific \& Academic Publishing 5(4): 157-168.

12. Anderson JB, Jolly DA, Green RD (2005) Determinants of farmer adoption of organic production methods in the fresh-market produce sector in California: A logistic regression analysis. Western Agricultural Economics Association Annual Meeting, San Francisco, California.

13. Gedikoglu H, McCann L, Artz G (2011) Off-Farm Employment Effects on Adoption of Nutrient Management Practices." Agricultural and Resource Economics Review 40: 293-306.

14. Ward CE, Vestal MK, Doye DG, Lalman DL (2008) Factors affecting adoption of cow-calf production practices in Oklahoma. Journal of Agricultural and Applied Economics 40(3): 851-863.

15. Pandit M, Mishra AK, Paudel KP, Larkin SL, Rejesus RM, et al. (2011) Reasons for Adopting Precision Farming: A Case Study of US Cotton Farmers. Paper presented at Southern Agricultural Economics Association Annual Meeting, Corpus Christi, Texas, US.

16. Fernandez-Cornejo J, Daberkow S, McBride WD (2001) Decomposing the size effect on the adoption of Innovations. Ag. Bio. Forum 4: 124136.

17. Khanna M (2001) Sequential adoption of site-specific technologies and its implications for nitrogen productivity: A double selectivity model. American Journal of Agricultural Economics 83(1): 35-51. 
18. Nyaupane NP, Gillespie J (2009) The influences of land tenancy and rotation selection on crawfish farmers' adoption of best management practices. Selected Paper Prepared for Presentation at the 2009 Southern Agricultural Economics Association Meeting, San Antonio, USA.

19. Tosakana NSP, Van Tassell LW, Wulfhorst JD, Boll J, Mahler R, et al. (2010) Determinants of the adoption of conservation practices by farmers in the Northwest Wheat and Range Region. Journal of Soil and Water Conservation 65(6): 404-412.

20. Baffoe-Asare R, Danquah JA, Annor-Frempong F (2013) Socioeconomic Factors Influencing Adoption of Codapec and Cocoa High-tech Technologies among Small Holder Farmers in Central Region of Ghana. American Journal of Experimental Agriculture 3: 277-292.

21. Rodríguez-Entrena M, Arriaza M (2013) Adoption of conservation agriculture in olive groves: Evidences from southern Spain. Land Use Policy 34(1): 294-300.

22. Caswell M, Fuglie K, Ingram C, Jans S, \& Kascak C (2001) Adoption of Agricultural Production Practices: Lessons Learned from the U.S Department of Agriculture Area Studies Project. Resource Economics Division, Economic Research Service, Department of Agriculture, Agricultural Economic Report No. 792, US

23. Gillespie JM, Davis CG (2004) Factors Influencing the Adoption of Breeding Technologies in US Hog. Journal of Agricultural and Applied Economics 36(1): 1-13.

24. Kim S, Gillespie JM, Paudel KP (2005) The effect of socioeconomic factors on the adoption of best management practices in beef cattle production. Journal of Soil and Water Conservation 60(3): 111-120.

25. Wachinger G, Renn O, Begg C \& Kuhlicke C (2013) The risk perception paradox-implications for governance and communication of natural hazards. Risk analysis 33(6): 1049-1065.

26. Yiridoe EK, Atari DOA, Gordon R, Smale S (2010) Factors influencing participation in the Nova Scotia environmental farm plan program. Land Use Policy 27(4): 1097-1106.

27. Kolade 0, Harpham T (2014) Impact of cooperative membership on farmers' uptake of technological innovations in Southwest Nigeria Development Studies Research 1(1): 340-353.

28. Eastwood C, Klerkx L, \& Nettle R (2017) Dynamics and distribution of public and private research and extension roles for technological innovation and diffusion: Case studies of the implementation and adaptation of precision farming technologies. Journal of Rural Studies 49: $1-12$.

29. Belin J, Hobrach J, Oltra V (2011) Determinants and specificities of eco-innovations-An econometric analysis for the French and German industry based on the Community Innovation Survey. Groupe de Recherche en Economie Théorique et Appliquée. France.

30. Toborn J \& Harvesting RW (2011) Adoption of agricultural innovations, converging narratives, and the role of Swedish agricultural research for development. Unpublished discussion paper.
31. Baumgart-Getz A, Prokopy LS, Floress K (2012) Why farmers adopt best management practice in the United States: A meta-analysis of the adoption literature. Journal of environmental management 96(1): 1725.

32. Sin I (2012) The adoption of environmentally friendly technologies in agriculture. Motu note. 1: 1-15

33. Liu EM (2013) Time to change what to sow: Risk preferences and technology adoption decisions of cotton farmers in China. Review of Economics and Statistics 95: 1386-1403.

34. Adesina AA, Mbila D, Nkamleu GB, Endamana D (2000) Econometric analysis of the determinants of adoption of alley farming by farmers in the forest zone of southwest Cameroon. Agriculture, Ecosystems \& Environment 80(3): 255-265.

35. Koundouri P, Nauges C, Tzouvelekas V (2006) Technology Adoption under Production Uncertainty: Theory and Application to Irrigation Technology. American Journal of Agricultural Economics 88(3): 657670 .

36. Kaci A, Cheriet F (2013) Analyse de la compétitivité de la filière de viande de volaille en Algérie: tentatives d'explication d'une déstructuration chronique. New Medit 12:11-22.

37. Meffeja F, Dogmo T, Njifutie N, Tchakounté J (2007) Influence de la substitution du tourteau de coton par le tourteau de palmiste dans l'alimentation des porcs en croissance finition. Livestock Research for Rural Development 19: 2.

38. Chehma A, FH Longo-Hammouda (2004) Bilan azoté et gain de poids, chez le dromadaire et le mouton, alimentés à base de sous-produits du palmier dattier, de la paille d'orge et du drinn Aristida pungens. Cahiers Agricultures 13: 221-226.

39. Zaidi F, Hassissene N, Boubekeur N, Bouaiche A, Bouabdellah A, et al. (2008) Étude in vitro de facteurs limitant la valeur nutritive du grignon d'olive: effets des matières grasses et des métabolites secondaires. Livestock Research for Rural Development 20: 3

40. Boudouma D (2009) Composition chimique du son de blé dur produit par les moulins industriels algériens. Livestock Research for Rural Development 21: 10.

41. Rafik A (2013) Incorporation du tourteau d'amande d'abricot en substitution au tourteau de soja dans l'alimentation des animaux domestique. Thèse de doctorat: Université de Batna. Algérie.

42. Anderson MD (1992) Reasons for new interest in on-farm research Biological Agriculture \& Horticulture 8(3): 235-250.

43. Guerin LJ, Guerin TF (1994) Constraints to the adoption of innovations in agricultural research and environmental management: a review. Australian Journal of Experimental Agriculture 34: 549-571.

44. Pannell DJ, Marshall GR, Barr N, Curtis A, Vanclay F, et al. (2006) Understanding and promoting adoption of conservation practices by rural landholders. Australian Journal of Experimental Agriculture 46: 1407-1424. 


\section{Your next submission with Juniper Publishers} will reach you the below assets

- Quality Editorial service

- Swift Peer Review

- Reprints availability

- E-prints Service

- Manuscript Podcast for convenient understanding

- Global attainment for your research

- Manuscript accessibility in different formats

( Pdf, E-pub, Full Text, Audio)

- Unceasing customer service

Track the below URL for one-step submission https://juniperpublishers.com/online-submission.php 